[6] Buriak, V. (2005). Rozvytok profesiino-pedahohichnykh yakostei u systemi bezperervnoi osvity. Vyshcha shkola, 2, 50-57.

[7] Lisina, L. O. (2011). Pidhotovka vchytelia v systemi pisliadyplomnoi pedahohichnoi osvity do konstruiuvannia navchalnykh tekhnolohii: teoretyko-metodolohichnyi aspekt. Zaporizhzhia: Plius 73, 471.

[8] Bielienka, H. V. (2011). Formuvannia profesiinoi kompetentnosti suchasnoho vykhovatelia doshkilnoho navchalnoho zakladu. Kyiv: Universytet, 320.

[9] Maslou, A. (2003). Motivatsiya i lichnost. Saint Petersburg: Izdatel'stvo «Piter», 352.

[10] Rodzhers, K. (2001). Stanovlenie lichnosti. Vzglyad na psikhoterapiyu. Moscow: EKSMO-Press, 416.

[11] Bekh, I. D. (2008). Vykhovannia osobystosti. Kyiv: Lybid, 848.

[12] Kh'ell, L., Zigler, D. (2002). Teorii lichnosti. Saint Petersburg: Izdatel'stvo «Piter», 608.

[13] Bekh, I. D. (2014). Innovatsiina vykhovna tekhnolohiia: sutnisni polozhennia ta shliakhy realizatsii. Pedahohichnyi visnyk, 4, 14-17.

[14] Bartkiv, O. (2010). Hotovnist pedahoha do innovatsiinoi profesiinoi diialnosti. Problemy pidhotovky suchasnoho vchytelia, 1, 52-58.

[15] Uruskyi, V. I. (2005). Formuvannia hotovnosti vchyteliv do innovatsiinoi diialnosti. Ternopil: TOKIPPO, 96.

\title{
COMPARISON OF TRADITIONAL AND INTERACTIVE TEACHING METHODS OF FIRST MEDICAL CARE FOR PHARMACISTS AT THE POST-GRADUATE STAGE OF TRAINING: RANDOMIZED, PROSPECTIVE STUDY
}

\author{
Mykhailo Omelchuk \\ Department of Surgery, Anesthesiology end intensive Care Postgraduate Education \\ Bogomolets National Medical University \\ 13 Shevctenko blvd., Kyiv, Ukraine, 01601 \\ omelchuk_mikhailo@ukr.net \\ Igor Sirenko \\ Department of Surgery, Anesthesiology end intensive Care Postgraduate Education \\ Bogomolets National Medical University \\ 13 Shevctenko blvd., Kyiv, Ukraine, 01601 \\ igor.sirenko.1988@gmail.com
}

\footnotetext{
Abstract

The aim of our work is to study and compare interactive and traditional teaching methods of pharmacists-interns for first medical care at the post-graduate educational stage.

To prove statistically or to deny advantages of interactive teaching methods, such as: simulation training, based on clinical cases, interactive lecture, close discussion, Peyton's 4 steps approach, positive criticism, based on two groups of pharmacists-interns, assessing the formed competence, stress-resistance and motivation for giving first medical care.

This is a prospective, randomized, pilot study with two groups of pharmacists-interns at studying at the internship from 2014 to 2017 year, based on the Institute of post-graduate education of the National medical university (NMU), named after O. O. Bogomolets, at one of learning stages - «Care at urgent states and acute intoxications". The participants were randomized and divided in two groups. There was formed the control group (CG), including 95 pharmacists-interns of 2014 year of admission, and in further the training was started according to the traditional methodology that doesn't provide interactive methods and simulation. The experimental group (EG) included 104 pharmacists-interns of 2015 year of admission that the program using interactive methods was elaborated for. Interactive methods used in the experimental group, included: simulation training, based on clinical scenarios, interactive lecture, close discussion, practical activity using Peyton's 4 steps approach, positive criticism. Activities lasted 12 hours
} 
in groups of 16 persons, there were also used diverse handbooks and posters according to ERC recommendations. Exclusion criteria were missing classes or failing a course.

Indices of the experimental group demonstrated the growth of assuredness level at giving urgent care (UC) up to $75,0 \%$. The number of interns, satisfied with the structure and methodology of giving information - up to $92,3 \%$. The analysis of data, received at assessing tests, demonstrated that $85,6 \%$ (high and middle) of EG at the final level (FL) of assessing fixed correctly the signs of the blood circulation stop comparing with $17,3 \%$ in the initial result (IR); $86,5 \%$ (high and middle) indicated correctly the time, given for conforming the blood circulation stop at FL comparing with $22,1 \%$ in IR; $80,8 \%$ (high and middle) chose the tactics at the blood circulation stop correctly at FL comparing with $28,8 \%$ in IR; the number of pharmacists-interns, who know medicaments, administered at CPR grew from 31,7 \% at IR to $90,4 \%$ (high and middle) at FL; at the beginning of studying only $6,7 \%$ chose the tactics at giving first medical care to traumatized patients correctly, at the final assessment - 69,2 \% (high and middle) in FR.; 88,4 \% (high and middle) chose the technique of stopping bleeding in FR comparing with 54,8 \% in IR.

The results of the initial and final assessing of formation levels of the competence in the control group (CG) didn't statistically differ.

Our study considered the new model of the curriculum using interactive teaching methods comparing with the traditional one. Interactive methods such as simulation training, based on clinical scenarios, interactive lecture, close discussion, Peyton's 4 steps approach, positive criticism demonstrated their effectiveness.

Keywords: Simulation training, interactive methods, Peyton's 4 steps approach, post-graduate education, pharmacists-interns.

\section{Introduction}

The history of modern simulation study begins from the beginning of XX century, when the training equipment for training skills of managing a plane Antoinette was firstly used in 1909 in aviation. In 1929 year an American engineer Edwin Link patented the training equipment for training pilots to fly by radio bearing [1].

The history of simulation training in medicine goes from the deep antiquity and is inseparably connected with the development of medical science. As to first phantoms, kept till now, there are ones for childbirth of XVIII century, by Angelika de Cudre, who invented her own methodology of simulation training for midwives [2, 3]. In 1957 Peter Safar, the head of the department of reanimation of the city Baltimore, USA, had published the book «ABC resuscinanion», where had been presented CPR (cardio-pulmonary reanimation) bases that became revolutionary in principles of giving urgent care. It inspired the Norwegian doctor Bjorn Lind and entrepreneur Asmund Laerdal for creating the first mannequin for making CPR, known as Resusci Anne (Ann, returned to life). The first computer mannequin was designed by the engineer Stephan Abrahamson and doctor Djadson Danson in the University of Southern California in the middle 60-ies [4]. Then due to the development of computer technique and microelectronics, there appeared complicated high-technological mannequins that allow to open a true potential of simulation training, and in 1994 there was created SESAM - European association of simulation in medicine that annually organizes international conferences, devoted to the development and introduction of simulation training technologies in medicine [5].

Theoretical foundations of simulation training as one of interactive training methods in medicine were formulated by the professor of Harvard Medicine School, David Gaba. He defined simulation as a technique (method), directed on changing or spreading the real experience using managed ones, based on modeling different aspects of the real world in the interactive mode [6].

Under modern conditions the method of simulation training is widely introduced in medical education throughout the world, especially the European council of reanimation, American cardiac association and other elaborated short courses, based on guidelines for cardio-pulmonary reanimation, using simulation training as a main method both for physicians and other people.

\section{Aim of research}

The aim of the study was to compare interactive and "traditional" teaching methods, used by us at training pharmacists-interns for first medical care at the post-graduate educational stage. 


\section{Materials and Methods}

This is a prospective, randomized, pilot study with two groups of pharmacists-interns at studying at the internship from 2014 to 2017 year, based on the Institute of post-graduate education of the National medical university (NMU), named after O. O. Bogomolets, at one of learning stages - «Care at urgent states and acute intoxications". The study was conducted based on recommendations of the European council of reanimation in 2010-2015 [7, 8].

At the beginning of training at the internship there was conducted a testing among pharmacists-interns of 2014 and 2015 years of admission. The participation in it was voluntary. The participants were randomized and divided in two groups. There was formed the control group (CG), including 95 pharmacists-interns of 2014 year of admission, and in further the training was started according to the traditional methodology by the ordinary curriculum and program of the specialty "general pharmacy" that doesn't provide interactive training methods and simulation.

The experimental group (EG) included 104 pharmacists-interns of 2015 year of admission that the program using interactive methods was elaborated for.

Interactive methods, used in the experimental group, included: simulation training, based on clinical scenarios, interactive lecture, close discussion, practical activity using Peyton's 4 steps methodology [9-11], positive criticism[12, 13]. Activities lasted 12 hours in groups of 16 persons, there were also used diverse handbooks and posters according to ERC recommendations. Exclusion criteria were missing classes or failing a course.

\section{Experimental procedures}

\section{1. Teachers}

The teachers were certificated instructors of the European reanimation council for the course Advanced Life Support (ALS), and also teachers, trained and competent in interactive and simulation training methods.

\section{2. Blindness, confidentiality, ethics}

All participants of the experiment voluntarily agreed participation and processing of personal data and questionnaire in written form. Participants were not informed about aims and methods of the study, they were only informed about their participation in it.

\section{3. Randomization}

Randomization was realized by age, gender, preliminarily acquired higher medical education by the specialty "Treating work", successes in training at the pre-graduate stage, preliminary secondary medical education, experience in working at medical institutions, and additional courses for UC before admission at the internship beyond the training program of higher medical educational institutions. Randomization results (Table 1).

Table 1

Characteristics of pharmacists-interns, included in the study

\begin{tabular}{|c|c|c|c|}
\hline Parameter & CG $(n=95)$ & EG $(n=104)$ & $\mathbf{P}^{*}$ \\
\hline Gender $\mathrm{m} / \mathrm{f}$ & $25 / 70$ & $26 / 78$ & $* * \mathbf{p}>0.05$ \\
\hline Age, years M [QI-QIII]) & $23(22-26)$ & $24(22-27)$ & ${ }^{*} \mathbf{p}>\mathbf{0 . 0 5}$ \\
\hline Finished medical education by the specialty "Treating work" yes/no & $18(18.9 \%)$ & $20(19.23 \%)$ & ${ }^{*} \mathbf{p}>\mathbf{0 . 0 5}$ \\
\hline Mean point at pre-graduate training & $3,9 \pm 0,5$ & $4 \pm 0,4$ & $* p>0.05$ \\
\hline Secondary medical education & $28(29,5 \%)$ & $32(30,7 \%)$ & $* \mathbf{p}>0.05$ \\
\hline Experience of working in TPI more than 1 year & $9(9,5 \%)$ & $10(9,6 \%)$ & $* \mathbf{p}>0.05$ \\
\hline Experience of additional courses of UC & $5(5,3 \%)$ & $6(5,7 \%)$ & $* \mathbf{p}>0.05$ \\
\hline
\end{tabular}


The conducted analysis didn't reveal any statistically significant difference that gives grounds to consider the groups as homogenous.

\section{4. Assessment of results}

The following step of the experiment was the assessment of the initial first care competence formation level in pharmacists-interns, who mastered the material, provided for training at the pre-graduate stage (traditional training methods) successfully, by testing. There were also assessed motivation and readiness for giving first medical care by questioning.

Then the control group was trained by traditional methods - without using interactive ones. In the experimental group the training was realized by the elaborated program, using interactive training methods and simulation. After finishing training the repeated questioning and testing of pharmacists-interns were realized in both groups.

For analyzing questioning results better, there were elaborated competence formation criteria, including: determination of the motivation level for giving urgent care and stress-resistance. The check of knowledge was conducted by testing using the format A (one correct answer), based on clinical cases or choosing an optimal tactics or medicament for each urgent state. The test was considered as done (positive result), if an intern got more than $70 \%$ of correct answers.

All criteria were divided in three levels - «low», «middle», «high». We based on the position, according to which the low level of competence formation is inadmissible, because it would make first medical care impossible because of the lack of knowledge and skills and also the low motivation and readiness for it, so we determined a sum of the middle and high levels as enough at comparing formation levels of components of the studied competence.

\section{5. Statistical methods}

The check of the statistical reliability of the received experimental data was realized using software: free standard package Microsoft Excel 2016 MSO. For determining the type of distribution, there was used Pearson's analysis with comparing measured parameters with calculated ones, expected at normal distribution.

At the limited number of observations, the great importance was inherent to the distribution of variables in the groups, because an occasional deviation of even one observation essentially influenced the averaged result. At getting data, which distribution differs from the normal one, in groups, it is impossible to use parametric methods, so their non-parametric analogues were used in this case [15]. Most data, gotten as a result of the study, were normally distributed.

For comparing the received research results, there was used Pearson's criterion $\chi^{2}$ (xi-square) [16]. The use of the statistical criterion $\chi^{2}$ allows to reveal, is there a difference in competence formation levels, and what reliability of the revealed differences is. We based on the fact that the change of the level of each competence component may take place as a result of occasional factors or under the influence of the offered training model.

For determining the reliability of differences between indices of the control and experimental group, there was offered the zero hypothesis $\left(\mathrm{H}_{0}\right)$, that states that the difference between indices of the control group (CG), included pharmacists-interns, trained by the standard curriculum and ones of the experimental group (EG) is statistically insignificant. As opposite to it, we offer an alternative hypothesis $\left(\mathrm{H}_{1}\right)$ of our study about the expedience of the elaborated program of pedagogical training. The difference between indices was considered as statistically significant at the reliability of correctness of the zero hypothesis less than $5 \%(\mathrm{p}<0,05)$. At revealing the statistically significant difference between the groups, the zero hypothesis is declined, and the alternative one is accepted. $\left(\mathrm{H}_{0}\right)=\mathrm{CG}=\mathrm{EG} ;\left(\mathrm{H}_{1}\right)=\mathrm{CG} \neq \mathrm{EG}$ at $\alpha \leq 0,05$.

For accepting a conclusion about results of the statistical check, we were guided by the rule: if the factual value of $\chi^{2}$ criterion enters the critical area, determined by statistical tables (that is Tfact. $<$ Tcr.), the zero hypothesis is accepted $\left(\mathrm{H}_{0}\right)-$ in this case the gotten differences are statistically insignificant and are the result of an occasional impact. If Tfact. $>$ Tcr. So, according to $\chi^{2}$ criterion, the difference in formation levels of the studied competence is statistically significant 
and cannot be explained by occasional causes, but is a result of the purposeful activity [17]. So, we decline the zero hypothesis, and our alternative hypothesis is proved. So, the received results are caused by systematically acting factors. It means that the elaborated pedagogical model influence the result effectively.

\section{Results}

\section{1. Questionnaire (initial level)}

Structured results (Table 2, 3).

According to the assessment of motivation and readiness to giving first medical care in pharmacists-interns, just started their training in the internship by the specialty "General pharmacy", there were revealed the additional and high motivation levels $-92,6 \%$ in CG and $92,3 \%$ in EG, but among interns, who gave medical care earlier, only 6,3\% in CG and 7,7 \% in EG felt themselves sure, and 58,9 \% in CG and 58,7 \% in EG felt the lack of knowledge at giving urgent care. It must be noted that $50,5 \%$ of CG and $50,0 \%$ of EG are not satisfied with the structure and methodology of presenting information of urgent care at training at the pre-graduate stage, but $96,1 \%$ of CG and $93,4 \%$ of EG considered the course of urgent care as obligatory at training at the internship.

Table 2

Questioning results (Primary level)

\begin{tabular}{|c|c|c|c|c|c|c|}
\hline \multirow{3}{*}{ Parameter } & \multicolumn{6}{|c|}{ Result } \\
\hline & \multicolumn{2}{|c|}{ Low } & \multicolumn{2}{|c|}{ Middle } & \multicolumn{2}{|c|}{ High } \\
\hline & CG $n=95$ & EG $n=104$ & CG $n=95$ & EG $n=104$ & CG $n=95$ & EG $n=104$ \\
\hline \multirow{2}{*}{ Desire to give UC if necessary } & 7 & 8 & 51 & 56 & 37 & 40 \\
\hline & $(7,4 \%)$ & $(7,7 \%)$ & $(53,7 \%)$ & $(53,8 \%)$ & $(38,9 \%)$ & $(38,5 \%)$ \\
\hline \multirow{2}{*}{$\begin{array}{l}\text { Experience of giving UC for } \\
\text { patients }\end{array}$} & 64 & 71 & 21 & 22 & 10 & 11 \\
\hline & $(67,4 \%)$ & $(68,3 \%)$ & $(22,1 \%)$ & $(21,2 \%)$ & $(10,5 \%)$ & $(10,6 \%)$ \\
\hline \multirow{2}{*}{$\begin{array}{l}\text { If yes, feeling of the lack of } \\
\text { knowledge at giving UC }\end{array}$} & 50 & 55 & 35 & 37 & 10 & 12 \\
\hline & $(52,6 \%)$ & $(52,9 \%)$ & $(36,8 \%)$ & $(35,6 \%)$ & $(10,5 \%)$ & $(11,5 \%)$ \\
\hline \multirow{2}{*}{$\begin{array}{l}\text { Assuredness at giving UC if nec- } \\
\text { essary after finishing HMEI }\end{array}$} & 56 & 61 & 33 & 35 & 6 & 8 \\
\hline & $(58,9 \%$ & $(58,7 \%)$ & $(34,7 \%)$ & $(33,7 \%)$ & $(6,3 \%)$ & $(7,7 \%)$ \\
\hline \multirow{2}{*}{$\begin{array}{l}\text { Satisfaction with the structure and } \\
\text { methodology of presenting infor- } \\
\text { mation at training at HMEI }\end{array}$} & 48 & 52 & 38 & 44 & 9 & 8 \\
\hline & $(50,5 \%$ & $(50,0 \%)$ & $(40,0 \%)$ & $(42,3 \%)$ & $(9,5 \%)$ & $(7,7 \%)$ \\
\hline \multirow{2}{*}{$\begin{array}{l}\text { If UC course is needed by phar- } \\
\text { macists-interns at the internship }\end{array}$} & 8 & 10 & 71 & 77 & 16 & 17 \\
\hline & $(8,4 \%)$ & $(9,6 \%)$ & $(74,7 \%)$ & $(74,0 \%)$ & $(16,8 \%)$ & $(16,3 \%)$ \\
\hline
\end{tabular}

Note: *CG-control group; EG-experimental group; UC-urgent care

\section{2. Test for assessing the initial level of competence formation (primary level, $\mathrm{PL}$ )}

We can state that $89,5 \%(\mathrm{CG})$ and $88,5 \%$ (EG) couldn't detect a cause of the critical state in a patient, only 5,3\% (CG) and 3,8\% (EG) could detect the correct and admissible treatment at the urgent state, only 6,3\%(CG) and 6,7\% (EG) know the tactics and can work with an Automated external defibrillator (AED) in a case of the blood circulation stop, 78,9\% (CG) and $77,9 \%$ (EG) of pharmacists-interns have no effective communication at working in a team, $69,5 \%$ (CG) and 69,2\% (EG) cannot organize the coordinated and effective work in a team, only $10,5 \%(\mathrm{CG})$ and $10,6 \%(\mathrm{EG})$ have leader qualities and can organize the effective work in a team of rescue workers. 
Based on the received results of the initial formation level of components of first pre-medical care competence in pharmacists-interns, who mastered the material, provided for training at the pre-graduate stage (traditional training methods) successfully, there was conducted the analysis of the results, xi-square test didn't reveal any statistically significant difference $<0,05$, that allows us to consider CG sample as identical to EG sample at the correspondent stage of the experiment, conducted at the beginning of training in the internship.

Table 3

Testing results (Primary level)

\begin{tabular}{|c|c|c|c|c|c|c|}
\hline \multirow{3}{*}{ Parameter } & \multicolumn{6}{|c|}{ Result } \\
\hline & \multicolumn{2}{|c|}{ Low } & \multicolumn{2}{|c|}{ Middle } & \multicolumn{2}{|c|}{ High } \\
\hline & CG & EG & CG & EG & CG & EG \\
\hline \multirow{2}{*}{$\begin{array}{l}\text { Assessment of symptoms of the blood circu- } \\
\text { lation stop }\end{array}$} & 80 & 86 & 11 & 13 & 4 & 5 \\
\hline & $(84,2 \%)$ & $(82,7 \%)$ & $(11,6 \%)$ & $(12,5 \%)$ & $(4,2 \%)$ & $(4,8 \%)$ \\
\hline \multirow{2}{*}{$\begin{array}{l}\text { Time of searching for symptoms of the blood } \\
\text { circulation stop }\end{array}$} & 75 & 81 & 14 & 16 & 6 & 7 \\
\hline & $(78,9 \%)$ & $(77,9 \%)$ & $(14,7 \%)$ & $(15,4 \%)$ & $(6,3 \%)$ & $(6,7 \%)$ \\
\hline \multirow{2}{*}{ Choice of tactics at the blood circulation stop } & 60 & 64 & 32 & 36 & 3 & 4 \\
\hline & $(63,2 \%)$ & $(61,5 \%)$ & $(33,7 \%)$ & $(34,6 \%)$ & $(3,2 \%)$ & $(3,8 \%)$ \\
\hline \multirow{2}{*}{ CPR method } & 69 & 74 & 19 & 21 & 7 & 9 \\
\hline & $(72,6 \%)$ & $(71,2 \%)$ & $(20,0 \%)$ & $(20,2 \%)$ & $(7,4 \%)$ & $(8,7 \%)$ \\
\hline \multirow{2}{*}{ Choice of medicaments at CPR } & 66 & 71 & 18 & 20 & 11 & 13 \\
\hline & $(69,5 \%)$ & $(68,3 \%)$ & $(18,9 \%)$ & $(19,2 \%)$ & $(11,6 \%)$ & $(12,5 \%)$ \\
\hline \multirow{2}{*}{ Choice of tactics of actions at UC at traumas } & 90 & 99 & 4 & 3 & 1 & 2 \\
\hline & $(94,7 \%)$ & $(95,2 \%)$ & $(4,2 \%)$ & $(2,9 \%)$ & $(1,1 \%)$ & $(1,9 \%)$ \\
\hline \multirow{2}{*}{$\begin{array}{l}\text { Assessment and choice of method of stopping } \\
\text { bleeding }\end{array}$} & 44 & 47 & 38 & 43 & 13 & 14 \\
\hline & $46,3 \%)$ & $(45,2 \%)$ & $(40,0 \%)$ & $(41,3 \%)$ & $(13,7 \%)$ & $(13,5 \%)$ \\
\hline \multirow{2}{*}{ Assessment and tactics at breast traumas } & 89 & 97 & 6 & 7 & 0 & 0 \\
\hline & $93,7 \%)$ & $(93,3 \%)$ & $(6,3 \%)$ & $(6,7 \%)$ & $(0,0 \%)$ & $(0,0 \%)$ \\
\hline \multirow{2}{*}{ Determination of causes of a critical state } & 85 & 92 & 8 & 9 & 2 & 3 \\
\hline & $(89,5 \%)$ & $(88,5 \%)$ & $(8,4 \%)$ & $(8,7 \%)$ & $(2,1 \%)$ & $2,9 \%)$ \\
\hline \multirow{2}{*}{$\begin{array}{l}\text { Algorithm of using medicamentous treatment } \\
\text { at UC }\end{array}$} & 60 & 67 & 30 & 33 & 5 & 4 \\
\hline & $(63,2 \%)$ & $(64,4 \%)$ & $(31,6 \%)$ & $(31,7 \%)$ & $(5,3 \%)$ & $3,8 \%)$ \\
\hline \multirow{2}{*}{ Tactics and technique of using AED } & 57 & 63 & 32 & 34 & 6 & 7 \\
\hline & $(60,0 \%)$ & $(60,6 \%)$ & $(33,7 \%)$ & $(32,7 \%)$ & $(6,3 \%)$ & $6,7 \%)$ \\
\hline
\end{tabular}

Note: *CG-control group; EG-experimental group; UC-urgent care; $C P R$-cardio-pulmonary reanimation

\section{3. Questioning (final result FR)}

The structured results are presented in Table 4, $\mathbf{5}$.

We can state that after finishing the course of giving first pre-medical care in pharmacists-interns of the experimental group, among the indices there was revealed the growth of the 
assuredness level at giving UC up to 75,0 \%. The number of interns, satisfied with the structure and methodology of presenting information grew to $92,3 \%$ of FR. Only 3 of 104 pharmacists-interns that is $2,9 \%$ of EG considered the course of urgent care as non-obligatory at training. The share of interns from EG, who are motivationally ready for training and desire to give UC if necessary remains high- $97,1 \%$ of FR after finishing the program.

Table 4

Comparison of the results of questioning, experimental group (final result)

\begin{tabular}{|c|c|c|c|c|c|c|}
\hline \multirow{3}{*}{ Parameter } & \multicolumn{6}{|c|}{ Result } \\
\hline & \multicolumn{2}{|c|}{ Low } & \multicolumn{2}{|c|}{ Middle } & \multicolumn{2}{|c|}{ High } \\
\hline & Initial & Final & Initial & Final & Initial & Final \\
\hline \multirow{2}{*}{ Desire to give UC if necessary } & 8 & 3 & 56 & 15 & 40 & 86 \\
\hline & $(7,7 \%)$ & $(2,9 \%)$ & $(53,8 \%)$ & $(14,4 \%)$ & $(38,5 \%)$ & $(82,7 \%)$ \\
\hline \multirow{2}{*}{$\begin{array}{l}\text { Experience of giving UC for } \\
\text { patients }\end{array}$} & 71 & 45 & 22 & 44 & 11 & 115 \\
\hline & $(68,3 \%)$ & $(43,3 \%)$ & $(21,2 \%)$ & $(42,3 \%)$ & $(10,6 \%)$ & $(14,4 \%)$ \\
\hline \multirow{2}{*}{$\begin{array}{l}\text { If yes, feeling of the lack of } \\
\text { knowledge at giving UC }\end{array}$} & 55 & 30 & 37 & 57 & 12 & 17 \\
\hline & $(52,9 \%)$ & $(28,8 \%)$ & $(35,6 \%)$ & $(54,8 \%)$ & $(11,5 \%)$ & $(16,3 \%)$ \\
\hline \multirow{2}{*}{$\begin{array}{l}\text { Assuredness at giving UC if nec- } \\
\text { essary after finishing HMEI }\end{array}$} & 61 & 26 & 35 & 62 & 8 & 16 \\
\hline & $(58,7 \%)$ & $(25,0 \%)$ & $(33,7 \%)$ & $(59,6 \%)$ & $(7,7 \%)$ & $(15,4 \%)$ \\
\hline \multirow{2}{*}{$\begin{array}{l}\text { Satisfaction with the structure and } \\
\text { methodology of presenting infor- } \\
\text { mation at training at HMEI }\end{array}$} & 52 & 8 & 44 & 60 & 8 & 36 \\
\hline & $(50,0 \%)$ & $(7,7 \%)$ & $(42,3 \%)$ & $(57,7 \%)$ & $(7,7 \%)$ & $(34,6 \%)$ \\
\hline \multirow{2}{*}{$\begin{array}{l}\text { If UC course is needed by phar- } \\
\text { macists-interns at the internship }\end{array}$} & 10 & 3 & 77 & 21 & 17 & 80 \\
\hline & $(9,6 \%)$ & $(2,9 \%)$ & $(74,0 \%)$ & $(20,2 \%)$ & $(16,3 \%)$ & $(76,9 \%)$ \\
\hline
\end{tabular}

\section{4. Testing (final result FR)}

The analysis of data, received at assessing tests, demonstrated that 85,6\% (high and middle) of EG at the final level (FL) of assessing fixed correctly the signs of the blood circulation stop comparing with $17,3 \%$ in IR; $86,5 \%$ (high and middle) indicated correctly the time, given for conforming the blood circulation stop at FL comparing with $22,1 \%$ in IR; 80,8 \% (high and middle) chose the tactics at the blood circulation stop correctly at FL comparing with $28,8 \%$ in IR; the number of pharmacists-interns, who know medicaments, administered at CPR grew from $31,7 \%$ at IR to $90,4 \%$ (high and middle) at FL; at the beginning of studying only $6,7 \%$ chose the tactics at giving first medical care to traumatized patients correctly, at the final assessment - 69,2\% (high and middle) in FR.; 88,4 \% (high and middle) chose the technique of stopping bleeding in FR comparing with $54,8 \%$ in IR.

The results of the primary and final assessment of formation levels of components of the competence in the control group at the primary stage of the experiment are presented in Table 6, 7. Using xi-square criterion for checking the relevancy of the offered zero hypothesis, there was not revealed any statistically important difference (at the value level $p \leq 0.05$ ) between the primary (PL) and final (FL) levels in the control group that gives grounds to prove the zero hypothesis and to deny the alternative one $(\mathrm{H} 0)=\mathrm{PL}=\mathrm{FL}$ at $\alpha \leq 0,05$, that with $95 \%$ reliability indicates that the difference between the primary (PL) and final (FL) levels of the control group (CG) is statistically insignificant. 
Table 5

Comparison of testing results, experimental group (final result)

\begin{tabular}{|c|c|c|c|c|c|c|}
\hline \multirow{3}{*}{ Parameter } & \multicolumn{6}{|c|}{ Result } \\
\hline & \multicolumn{2}{|c|}{ Low } & \multicolumn{2}{|c|}{ Middle } & \multicolumn{2}{|c|}{ High } \\
\hline & Initial & Final & Initial & Final & Initial & Final \\
\hline \multirow{2}{*}{$\begin{array}{l}\text { Assessment of symptoms of the blood circu- } \\
\text { lation stop }\end{array}$} & 86 & 15 & 13 & 34 & 5 & 55 \\
\hline & $(82,7 \%)$ & $(14,4 \%)$ & $(12,5 \%)$ & $(32,7 \%)$ & $(4,8 \%)$ & $(52,9 \%)$ \\
\hline \multirow{2}{*}{$\begin{array}{l}\text { Time of searching for symptoms of the blood } \\
\text { circulation stop }\end{array}$} & 81 & 14 & 16 & 20 & 7 & 70 \\
\hline & $(77,9 \%)$ & $(13,5 \%)$ & $(15,4 \%)$ & $(19,2 \%)$ & $(6,7 \%)$ & $(67,3 \%)$ \\
\hline \multirow{2}{*}{ Choice of tactics at the blood circulation stop } & 64 & 20 & 36 & 64 & 4 & 20 \\
\hline & $(61,5 \%)$ & $(19,2 \%)$ & $(34,6 \%)$ & $(61,5 \%)$ & $(3,8 \%)$ & $(19,2 \%)$ \\
\hline \multirow{2}{*}{ CPR method } & 74 & 21 & 21 & 65 & 9 & 18 \\
\hline & $(71,2 \%)$ & $(20,2 \%)$ & $(20,2 \%)$ & $(62,5 \%)$ & $(8,7 \%)$ & $(17,3 \%)$ \\
\hline \multirow{2}{*}{ Choice of medicaments at CPR } & 71 & 10 & 20 & 68 & 13 & 26 \\
\hline & $(68,3 \%)$ & $(9,6 \%)$ & $(19,2 \%)$ & $(65,4 \%)$ & $(12,5 \%)$ & $(25,0 \%)$ \\
\hline \multirow{2}{*}{ Choice of tactics of actions at UC at traumas } & 99 & 34 & 3 & 57 & 2 & 13 \\
\hline & $(95,2 \%)$ & $(32,7 \%)$ & $(2,9 \%)$ & $(54,8 \%)$ & $(1,9 \%)$ & $(12,5 \%)$ \\
\hline \multirow{2}{*}{$\begin{array}{l}\text { Assessment and choice of method of stopping } \\
\text { bleeding }\end{array}$} & 47 & 12 & 43 & 62 & 14 & 30 \\
\hline & $(45,2 \%)$ & $(11,5 \%)$ & $(41,3 \%)$ & $59,6 \%)$ & $(13,5 \%)$ & $(28,8 \%)$ \\
\hline \multirow{2}{*}{ Assessment and tactics at breast traumas } & 97 & 32 & 7 & 54 & 0 & 18 \\
\hline & $(93,3 \%)$ & $(30,8 \%)$ & $(6,7 \%)$ & $(51,9 \%)$ & $(0,0 \%)$ & $(17,3 \%)$ \\
\hline \multirow{2}{*}{ Determination of causes of a critical state } & 92 & 29 & 9 & 65 & 3 & 10 \\
\hline & $(88,5 \%)$ & $(27,9 \%)$ & $(8,7 \%)$ & $(62,5 \%)$ & $2,9 \%)$ & $(9,6 \%)$ \\
\hline \multirow{2}{*}{$\begin{array}{l}\text { Algorithm of using medicamentous treatment } \\
\text { at UC }\end{array}$} & 67 & 24 & 33 & 61 & 4 & 19 \\
\hline & $(64,4 \%)$ & $(23,1 \%)$ & $(31,7 \%)$ & $(58,7 \%)$ & $3,8 \%)$ & $(18,3 \%)$ \\
\hline \multirow{2}{*}{ Tactics and technique of using AED } & 63 & 13 & 34 & 51 & 7 & 40 \\
\hline & $(60,6 \%)$ & $(12,5 \%)$ & $(32,7 \%)$ & $(49,0 \%)$ & $(6,7 \%)$ & $(38,5 \%)$ \\
\hline
\end{tabular}

Note: * CPR - cardio-pulmonary reanimation; AED - automated external defibrillator; $C G$ - control group,;EG - experimental group; *UC-urgent care; $C P R$-cardio-pulmonary reanimation

Table 6

Comparison of questioning results, control group (final result)

\begin{tabular}{|c|c|c|c|c|c|c|}
\hline \multirow{3}{*}{ Parameter } & \multicolumn{6}{|c|}{ Result } \\
\hline & \multicolumn{2}{|c|}{ Low } & \multicolumn{2}{|c|}{ Middle } & \multicolumn{2}{|c|}{ High } \\
\hline & Initial & Final & Initial & Final & Initial & Final \\
\hline \multirow{2}{*}{ Desire to give UC if necessary } & 7 & 6 & 51 & 56 & 37 & 33 \\
\hline & $(7,4 \%)$ & $(6,3 \%)$ & $(53,7 \%)$ & $(58,9 \%)$ & $(38,9 \%)$ & $(34,7 \%)$ \\
\hline \multirow{2}{*}{ Experience of giving UC for patients } & 64 & 61 & 21 & 23 & 10 & 11 \\
\hline & $(67,4 \%)$ & $64,2 \%)$ & $(22,1 \%)$ & $(24,2 \%)$ & $(10,5 \%)$ & $(11,6 \%)$ \\
\hline \multirow{2}{*}{$\begin{array}{l}\text { If yes, feeling of the lack of knowledge at } \\
\text { giving UC }\end{array}$} & 50 & 57 & 35 & 30 & 10 & \\
\hline & $(52,6 \%)$ & $(60,0 \%)$ & $(36,8 \%)$ & $(28,8 \%)$ & $10,5 \%)$ & $(8,4 \%)$ \\
\hline \multirow{2}{*}{$\begin{array}{l}\text { Assuredness at giving UC if necessary after } \\
\text { finishing HMEI }\end{array}$} & 56 & 57 & 33 & 34 & 6 & 4 \\
\hline & $(58,9 \%)$ & $(60,0 \%) \%)$ & $(34,7 \%)$ & $(35,8 \%)$ & $(6,3 \%)$ & $(4,2 \%)$ \\
\hline \multirow{2}{*}{$\begin{array}{l}\text { Satisfaction with the structure and method- } \\
\text { ology of presenting information at training } \\
\text { at HMEI }\end{array}$} & 48 & 50 & 38 & 35 & 9 & 10 \\
\hline & $(50,5 \%)$ & $(52,6 \%)$ & $(40,0 \%)$ & $(36,8 \%)$ & $(9,5 \%)$ & $(10,5 \%)$ \\
\hline \multirow{2}{*}{$\begin{array}{l}\text { If UC course is needed by pharmacists-in- } \\
\text { terns at the internship }\end{array}$} & 8 & 9 & 71 & 73 & 16 & 13 \\
\hline & $(8,4 \%)$ & $(9,5 \%)$ & $(74,7 \%)$ & $(76,8 \%)$ & $(16,8 \%)$ & $(13,7 \%)$ \\
\hline
\end{tabular}


Table 7

Comparison of the testing results, control group (final result)

\begin{tabular}{|c|c|c|c|c|c|c|}
\hline \multirow{3}{*}{ Parameter } & \multicolumn{6}{|c|}{ Result } \\
\hline & \multicolumn{2}{|c|}{ Low } & \multicolumn{2}{|c|}{ Middle } & \multicolumn{2}{|c|}{ High } \\
\hline & Initial & Final & Initial & Final & Initial & Final \\
\hline $\begin{array}{l}\text { Assessment of symptoms of the blood circu- } \\
\text { lation stop }\end{array}$ & $\begin{array}{c}80 \\
(84,2 \%)\end{array}$ & $\begin{array}{c}78 \\
(82,1 \%)\end{array}$ & $\begin{array}{c}11 \\
(11,6 \%)\end{array}$ & $\begin{array}{c}12 \\
(12,6 \%)\end{array}$ & $\begin{array}{c}4 \\
(4,2 \%)\end{array}$ & $\begin{array}{c}5 \\
(5,3 \%)\end{array}$ \\
\hline $\begin{array}{l}\text { Time of searching for symptoms of the blood } \\
\text { circulation stop }\end{array}$ & $\begin{array}{c}75 \\
(78,9 \%)\end{array}$ & $\begin{array}{c}74 \\
(77,9 \%)\end{array}$ & $\begin{array}{c}14 \\
(14,7 \%)\end{array}$ & $\begin{array}{c}16 \\
(16,8 \%)\end{array}$ & $\begin{array}{c}6 \\
(6,3 \%)\end{array}$ & $\begin{array}{c}5 \\
(5,3 \%)\end{array}$ \\
\hline Choice of tactics at the blood circulation stop & $\begin{array}{c}60 \\
(63,2 \%)\end{array}$ & $\begin{array}{c}58 \\
(61,1 \%)\end{array}$ & $\begin{array}{c}32 \\
(33,7 \%)\end{array}$ & $\begin{array}{c}33 \\
(34,7 \%)\end{array}$ & $\begin{array}{c}3 \\
(3,2 \%)\end{array}$ & $\begin{array}{c}4 \\
(4,2 \%)\end{array}$ \\
\hline CPR method & $\begin{array}{c}69 \\
(72,6 \%)\end{array}$ & $\begin{array}{c}63 \\
(66,3 \%)\end{array}$ & $\begin{array}{c}19 \\
(20,0 \%)\end{array}$ & $\begin{array}{c}23 \\
(24,2 \%)\end{array}$ & $\begin{array}{c}7 \\
(7,4 \%)\end{array}$ & $\begin{array}{c}9 \\
(9,5 \%)\end{array}$ \\
\hline Choice of medicaments at CPR & $\begin{array}{c}66 \\
(69,5 \%)\end{array}$ & $\begin{array}{c}62 \\
(65,3 \%)\end{array}$ & $\begin{array}{c}18 \\
(18,9 \%)\end{array}$ & $\begin{array}{c}21 \\
(22,1 \%)\end{array}$ & $\begin{array}{c}11 \\
(11,6 \%)\end{array}$ & $\begin{array}{c}12 \\
(12,6 \%)\end{array}$ \\
\hline Choice of tactics of actions at UC at traumas & $\begin{array}{c}90 \\
(94,7 \%)\end{array}$ & $\begin{array}{c}85 \\
(89,5 \%)\end{array}$ & $\begin{array}{c}4 \\
(4,2 \%)\end{array}$ & $\begin{array}{c}8 \\
(8,4 \%)\end{array}$ & $\begin{array}{c}1 \\
(1,1 \%)\end{array}$ & $\begin{array}{c}2 \\
(2,1 \%)\end{array}$ \\
\hline $\begin{array}{l}\text { Assessment and choice of method of stopping } \\
\text { bleeding }\end{array}$ & $\begin{array}{c}44 \\
(46,3 \%)\end{array}$ & $\begin{array}{c}39 \\
(41,1 \%)\end{array}$ & $\begin{array}{c}38 \\
(40,0 \%)\end{array}$ & $\begin{array}{c}42 \\
(44,2 \%)\end{array}$ & $\begin{array}{c}13 \\
(13,7 \%)\end{array}$ & $\begin{array}{c}14 \\
(14,7 \%)\end{array}$ \\
\hline Assessment and tactics at breast traumas & $\begin{array}{c}89 \\
(93,7 \%)\end{array}$ & $\begin{array}{c}87 \\
(91,6 \%)\end{array}$ & $\begin{array}{c}6 \\
(6,3 \%)\end{array}$ & $\begin{array}{c}7 \\
(7,4 \%)\end{array}$ & $\begin{array}{c}0 \\
(0,0 \%)\end{array}$ & $\begin{array}{c}1 \\
(1,1 \%)\end{array}$ \\
\hline Determination of causes of a critical state & $\begin{array}{c}85 \\
(89,5 \%)\end{array}$ & $\begin{array}{c}81 \\
(85,3 \%)\end{array}$ & $\begin{array}{c}8 \\
(8,4 \%)\end{array}$ & $\begin{array}{c}12 \\
12,6 \%)\end{array}$ & $\begin{array}{c}2 \\
(2,1 \%)\end{array}$ & $\begin{array}{c}2 \\
(2,1 \%)\end{array}$ \\
\hline $\begin{array}{l}\text { Algorithm of using medicamentous treatment } \\
\text { at UC }\end{array}$ & $\begin{array}{c}60 \\
63,2 \%)\end{array}$ & $\begin{array}{c}52 \\
54,7 \%)\end{array}$ & $\begin{array}{c}30 \\
(31,6 \%)\end{array}$ & $\begin{array}{c}35 \\
(36,8 \%)\end{array}$ & $\begin{array}{c}5 \\
(5,3 \%)\end{array}$ & $\begin{array}{c}8 \\
(8,4 \%)\end{array}$ \\
\hline Tactics and technique of using AED & $\begin{array}{c}57 \\
(60,0 \%)\end{array}$ & $\begin{array}{c}54 \\
(51,9 \%)\end{array}$ & $\begin{array}{c}32 \\
33,7 \%)\end{array}$ & $\begin{array}{c}34 \\
(32,7 \%)\end{array}$ & $\begin{array}{c}6 \\
(6,3 \%)\end{array}$ & $\begin{array}{c}7 \\
(7,4 \%)\end{array}$ \\
\hline
\end{tabular}

Note: $C P R$ - cardio-pulmonary reanimation; AED - automated external defibrillator; UC - urgent care; CPR - cardio-pulmonary reanimation

\section{Discussion}

As we know, we compared the "traditional model" of training with interactive training methods at teaching pharmacists-interns at the post-graduate stage in Ukraine for the first time. The interactive methods, used by us, included simulation training, based on clinical cases. Such training methodology is very effective, because it gives a possibility to master and train skills of giving first care well, including ones of basic reanimation arrangements. The advantages of simulation training are the fact that training is realized under conditions, approximated to real ones, but safe for patients, and decreases a stress of an intern. This method allows also to make mistakes, and there is a good possibility to acknowledge and understand them at debriefing with further correcting at new scenarios. This methodology also gives a possibility for a great number of trials. In our study we have also demonstrated the advantage of this methodology over traditional training methods.

At mastering and learning practical skills of giving first medical care we used the methodology of Peyton's 4 steps. This approach to realization of the practical part of training is based on the 
partial mastering of a skill and includes four steps: Demonstration; Deconstruction; Understanding; Realization. Our work proves the effectiveness of this approach, but we know that there are studies about modification of this training methodology, conducted in medical education. Modification was in simplification to three and two steps [18]. From our point of view, it is necessary to study this question more detail in further.

We also used such methods as interactive lectures during $30 \mathrm{~min}$ and close discussions about first care in our study.

In whole the use of interactive methods was highly assessed by the participants of the study. From their point of view, interaction favored the full involvement in the training process, caused more interest to it and also raised motivation. The results of our work just statistically prove these statements. Participants of the study also stated that after studying on mannequins at simulation scenarios it is simpler for them to give first care to patients if necessary, because simulation favored the involvement of imagination and more real understanding of a situation.

Almost all participants of the study were satisfied with training and noted the need in increasing the course duration.

We find it necessary to note certain limitations of this study. One of them is the fact that the sample was rather small and assessed only one specialty that possibly limited the representativeness of the study. It must be also noted that most pharmacists-interns never underwent training with such structure of activities and methods that possibly caused even more interest to it. Our study didn't assess results of "surviving" of knowledge in prospects. We think that further studies must be realized in this direction, and training results must be assessed during time intervals.

\section{Conclusions}

1. There were compared interactive and traditional teaching methods of pharmacists-interns for first medical care.

2. There was proved the advantage of interactive training methods (simulation training, based on clinical scenarios, interactive lecture, close discussion, Peyton's 4 steps approach, positive criticism).

3. There were proved the expedience and necessity of introducing the interactive training methods in the curriculum of education of pharmacists-interns at the post-graduate stage as obligatory ones.

4. We find it necessary to conduct studies in this field for revealing additional advantages and shortcomings and a possibility of widening and introducing to other directions in medical education.

\section{References}

[1] Edwin Albert Link. A Chronological Biography". Binghamton University Libraries. Available at: https://www.binghamton.edu/libraries/special-collections/researchandcollections/linkedwin.html

[2] Rosen, K. R. (2008). The history of medical simulation. Journal of Critical Care, 23 (2), 157-166. doi: 10.1016/j.jcrc.2007.12.004

[3] Moran, M. E. (2010). Enlightenment via Simulation: “Crone-ology's”. First Woman. Journal Of Endourology, 24 (1), 5-8. doi: 10.1089/end.2009.0423

[4] Jones, F., Passos-Neto, C. E., Braguiroli, O. F. M. (2015). Simulation in Medical Education: Brief history and methodology. The Principles and Practice of Clinical Research, 1 (2), 56-63.

[5] Society in Europe for Simulation Applied to Medicine. Available at: http://www.sesam-web.org

[6] Gaba, D. M. (2004). The future vision of simulation in health care. Quality and Safety in Health Care, 13 (1), 2-10. doi: 10.1136/qshc.2004.009878

[7] Perkins, G. D., Handley, A. J., Koster, R. W., Castren, M., Smyth, M. A., Olasveengen, T. et. al. (2015). European Resuscitation Council Guidelines for Resuscitation 2015 Section 2. Adult basic life support and automated external defibrillation $\mathrm{n}$, on behalf of the Adult basic life support and automated external defibrillation. Resuscitationk, 95, 81-99. doi: 10.1016/j.resuscitation.2015.07.015 
[8] Koster, R. W., Baubin, M. A., Bossaert, L. L., Caballero, A., Cassan, P., Castrén, M. et. al. (2010). European Resuscitation Council Guidelines for Resuscitation 2010 Section 2. Adult basic life support and use of automated external defibrillators. Resuscitation, 81 (10), 1277-1292. doi: 10.1016/j.resuscitation.2010.08.009

[9] Lateef, F. (2010). Simulation-based learning: Just like the real thing. Journal of Emergencies, Trauma, and Shock, 3 (4), 348-352. doi: 10.4103/0974-2700.70743

[10] Peyton, J. W. (1998). Teaching and Learning in Medical Practice. Heronsgate, Rickmansworth: Manticore Europe Ltd, 256.

[11] Krautter, M., Weyrich, P., Schultz, J.-H., Buss, S. J., Maatouk, I., Junger, J., Nikendei, C. (2011) Effects of Peyton's Four-Step Approach on Objective Performance Measures in Technical Skills Training: A Controlled Trial. Teaching and Learning in Medicine, 23 (3), 244-250. doi: 10.1080/ 10401334.2011.586917

[12] Mandhane, N., Ansari, S., Shaikh, T., Deolekar, S. (2015). Positive feedback: a tool for quality education in field of medicine. International Journal of Research in Medical Sciences, 1868-1873. doi: 10.18203/2320-6012.ijrms20150293

[13] Qureshi, N. S. (2017). Giving effective feedback in medical education. The Obstetrician \& Gynaecologist, 19 (3), 243-248. doi: 10.1111/tog.12391

[14] Glantz, S. A. (2012). Primer of biostatistics. McGraw Hill Professional, 459.

[15] Davis, C. S. (2002). Statistical methods of the analysis of repeated measurements. New York: Springer, 744.

[16] Scott, I., Mazhindu, D. (2014). Statistics for Healthcare Professionals: An Introduction. SAGE Publications Ltd, 256.

[17] Munster, T., Stosch, C., Hindrichs, N., Franklin, J., Matthes, J. (2016). Peyton's 4-Steps-Approach in comparison: Medium-term effects on learning external chest compression - a pilot study. GMS Journal for Medical Education, 33 (4). doi: 10.3205/zma001059 